\title{
Functional Requirements of Pharmacy Information System in Hospitals
}

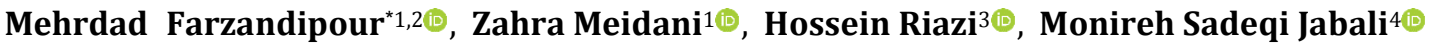 \\ 1- Health Information Management Research Center, Kashan University of Medical Sciences, Kashan, Iran. \\ 2- Department of Health Information Management/Technology, School of Allied Health Professions, Kashan University of Medical Sciences, Iran \\ 3- PhD Candidate of Medical Informatics, School of Allied Medical Sciences, Tehran University of Medical Sciences, Tehran, Iran \\ 4- MsC in Education Medical Records, Esabne Maryam Hospital, Isfahan University of Medical Sciences, Isfahan, Iran
}

\begin{abstract}
Introduction: Pharmacy Information System (PIS) existed in hospitals collects, saves and manages the information related to drug and drug consumption in process of caring patients and results in decreasing error in interpreting handwritten prescriptions, distributing drug and controlling side effects of drug. Regarding the importance of knowing users' expectations for designing successful system and based on procedure of clinical environment and in direction of patient' security and improving care quality, this study conducted with the aim of determining functional requirements of pharmacy information system and by offering system 'final users for poll.

Material and Methods: This research is descriptive cross-sectional one and of applied kind that conducted in 15 hospitals in 1391. This study conducted in three independent steps including library study, internet search and designing finding semi produced guideline and questionnaire, offering ten experts the finding semi produced questionnaire for poll, offering 50 individuals of experts the final questionnaire for poll using Delphi technique. Validity of final questionnaire and its reliability confirmed through validity of content and re-test test, respectively. Data analyzed using SPSS software and answers given points of 0-4 and requirements with mean' final point of 3 or more than 3 confirmed.

Results: Based on the first and second turns of Delphi technique, final list of pharmacy information system' functional requirements of 80 requirements determined. The highest mean point related to capability to connect with computerized provider order entry (3.73\%), capability to calculate dose of drug and warn about drug interference $(3.71 \%)$, capability to apply barcode technology (3.71\%) and capability to register expiration date, way and place of keeping good (3.63\%).

Conclusion: Based on experts' opinions, requirements that related to patient security were paid more attention. Finally, a list of pharmacy information system' functional requirements presented that could be used by designers, developers and other beneficiaries of pharmacy information system in hospitals.
\end{abstract}

Article History

Received: 2016-04-29

Accepted: 2016-08-06

Published: 2017-03-15

\section{Keywords}

Pharmacy Information System Hospital Information System

Pharmacy

Functional Requirements

\footnotetext{
* Corresponding Author: M Sadeqi Jabali, Esabne Maryam Hospital, Isfahan University of Medical Sciences, Isfahan, Iran (Email: msadeqi2005@gmail.com) 


\section{INTRODUCTION}

Making sure of patient' security is the highest priority of individuals employed in drug profession and medication errors are known as the most prevalent threat for patient' security [1] that is prevalent in hospital and can be prevented [2]. Based on report of medical association, 400000 cases of preventable harm of patients in America hospitals have annually been due to medication errors [1] . Results of a study indicated that 6.5 unpleasant events resulted from medication observed among 100 admitted patients that more than one-fourth of them had been preventable [ $\underline{3}$ ]. Effect of medication errors on quality of care and patient' security is a growing concern [4]. Primary consequence of medication errors is to increase the term of hospitalization, increase cost and sometimes serious harm and even death [ $[5]$. It was reflected in study of Hughes and Oritz that patients are being harmed by medication error die or become unable for more than six months in $30 \%$ of cases [ [6] Regarding frequency medication errors occurrence and its effect on quality of care and patient' security, it is necessary to research in the field of reasons for these errors and strategies for decreasing them [4]. Among the serious medication errors, approximately one-third are occurred in the phase of writing orders, one-third during in the phase of delivering drug and remained one-third in the phase of distributing drug and filling prescription [7]. Study of Al-Shara reflected that $8.7 \%$ of medication errors have been related to distributing drug by pharmacy []] . In study of Toruner and Uysal, nurses mentioned that $13.4 \%$ of primary reasons for medication errors occurrence are related to sending wrong drug and drug dose from pharmacy [1] . Pharmacy of hospital presents healthcare services by selecting, preparing, storing, compounding and distributing drug and drug equipment [9] and its activities are required retrieving, processing, comparing information and updating [10]. Applying information technology is known as an encouraging strategy in preventing from medication errors $[\underline{9}$, 11 12]. Therefore, implementing efficient, organized and secure drug-distributing system is necessary in order to control cost and make sure that physicians are prescribed securely and at the time of request [13]. Pharmacy's information system (PIS) is sub-system of hospital information system [14] that collects, stores and manages the information related to drug and consumption of drug in process of caring patient [15] and provides accurate and comprehensive information for patients, pharmacist, physicians, nurses and other providers of health care in respond to drug requests [16]. Activities of this system consisted of managing drug distribution, analyzing drug orders, presenting reports, providing patient's drug information, clinical surveillance through monitoring interference and drug allergy and management of pharmacy $[\underline{15}, \underline{17}-\underline{19}]$. This system results in decrease of errors related to incorrectly interpreting handwritten prescription, decrease of error in drug

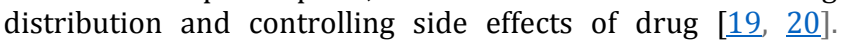
Conducted study by Bates reflected that PIS can considerably reduce medication errors [9]. Despite all these advantages, research of Collignon with title of pharmacy services for emergency ward of UK in 2010 showed that only $40 \%$ of requirements of medication are being registered in PIS [21]. Some studies have been also conducted in Iran in order to evaluate PIS; Emani and colleagues' study showed that extent of conformity of hospitals information system in hospitals of Shiraz Medical Science University with criteria of Physician Collage of America in pharmacy ward has been weak [22]. Saghaeinejad Isfahani and colleagues reflected in their study that input, process and output criteria of Pharmacist Association in PIS of Isfahan City's hospitals have not completely been observed with maximum means of $32.75 \%$, $43.95 \%$ and $26.15 \%$, respectively [23]. In Asadi and colleagues' study, information elements such as drug information, patients' information and information of prescriber are imperfectly being registered in PIS of educational and medical hospitals affiliated to Shahid Beheshti Uuiversity to the extent of 50.1\%, $21.9 \%$ and $33.3 \%$, respectively [16]. Farzandipour and colleagues' study reflected that hospitals information systems in Iran, with maximum conformity of $58.6 \%$, do not appropriately provide the expectations of pharmacy' users [24]. These systems must be designed based on aims and users' needs and support process and procedure of users' work in order to ensure success of health information system's tool [25]. McAlearnen mentioned focusing on working process as one of the strategies for succeeding information system [26] and Romano stated that functional requirements of system must be specified by users who use system [27]. Therefore, cooperating and making pharmacists and users participate in designing system through request for their information needs and their expectations from system are among measurements that can be effective in developing systems in proportion to their working processes and their need. Regarding the importance of knowing users' expectations for designing successful system and based on procedure of clinical environment and in direction of patient' security and improving care quality, this study conducted with the aim of determining functional requirements of PIS and by offering system 'final users for poll.

\section{MATERIAL AND METHODS}

This research is descriptive cross-sectional one and of applied kind that conducted in 2012. In first step, finding semi produced guideline and questionnaire prepared considering library studies and wide internet search in data bases such as Google scholar, Sciencedirect, Pubmed and Web of Science. Keywords of searching in information bases included hospital information system, electronic health records, pharmacy's information system, and patient's security and medication errors. Capabilities of pharmacy's information system listed in semi-structured produced questionnaire and an open-ended question existed at the end through that cases were asked that must be added to primary requirements in experts' opinion. In second step of research, semi produced guideline of finding emailed to 10 experts. Under-study experts were included pharmacy technical chairmen of hospitals. In primary questionnaire, none of requirements of pharmacy's information system were deleted and just some requirements suggested by experts. After analyzing content of material and concluding opinions presented in primary questionnaire, final questionnaire of requirements of pharmacy's information system drew up in three parts including 81 close-ended questions and open-ended question; demographic information considered age, gender, field of education, level of education, kind of employment, duration of job experience, duration of experience and job experience of working with pharmacy's information system of hospital. Closed questions drew up based on criteria and requirements of resulted from library study and concluding opinions of experts in first step and in the form of five-degree ranking from completely agree to completely disagree. Respective questionnaire surveyed in terms of validity and reliability by experts before offering for poll. Validity of questionnaire specified based on content validity method and receiving opinions of some experts and its reliability specified as $93 \%$ after re-sending 10 questionnaires to experts after seven days and calculating correlation coefficient among points resulted from measuring twice. Experts of the second step were including 50 individuals selected from technical chairmen, interior mangers and 
technicians interested to join the project, since they are final users of such systems. All participants had at least two years of working experience with pharmacy information system. A total of 15 hospitals in Isfahan and Tehran that randomly selected were studied. Totally 38 out of 50 questionnaires filled. Results were analyzed using SPSS software (ver. 18). Answers of completely disagree, disagree, no opinion, agree, and completely agree obtained $0,1,2,3$ and 4 points, respectively, and mean of final point of each requirement calculated. Requirements with mean score of equal or more than 3 was confirmed, while requirements with mean score of lower than 2 were rejected. The requirements with mean score between 2 and 3 returned to experts for re-poll until agreement made.

\section{RESULTS}

In this study, the majority of experts were female $(63.2 \%)$ and $36.8 \%$ of them were male. Average age of participants was $34.9 \pm 5.9$ years and the minimum and maximum age of participants was 26 and 45 years, respectively. As it shown in Table 1, the most of participants (57.9\%) held BA degree and the most of them had employed contractually (50\%) and average of job experience was $9 \pm 6.2$ years. Mean duration of operating and implementing hospital information system in selected hospitals was $4.2 \pm 1.57$ years and experts' job experience with hospital information system was $3.7 \pm 1.4$ years.

Table 1: Demographic information of experts

\begin{tabular}{|l|l|l|l|}
\hline Variables & & Number & Percentage \\
\hline Gender & Male & 14 & 36.8 \\
& Female & 24 & 63.2 \\
& total & 38 & 100 \\
\hline Level of & B.A & 22 & 57.9 \\
education & M.A. & 1 & 2.6 \\
& PH.D. & 15 & 39.5 \\
& total & 38 & 100 \\
\hline Kind of & Formal & 14 & 36.8 \\
employment & Provisional & 4 & 10.5 \\
& Contractual & 14 & 36.8 \\
& Other & 6 & 15.8 \\
& total & 38 & 100 \\
\hline
\end{tabular}

Results of this study reflected that requirements of using decision-support system in calculating dose of drug and warning about medicinal interaction, capability to use barcode technology, capability to connect with computerized provider order entry, capability to register expiration date and way and place of keeping drug are among the most important requirements of pharmacy' information system. This importance may be attributed to problems related to frequency of medication errors (Table 2).

Based on results, most of the experts agreed with existence of capability to calculate dose of drug based on medicinal histories and physiological parameters of patient and ability to change units for usage. Study conducted on hospitalized patients reflected that $60 \%$ of medication errors are related to making mistake in drug dose or period of drug consumption [28]. Chertow and colleague showed in their study that using decision-support system results in $13 \%$ decrease in inappropriate dose and $24 \%$ decrease in inappropriate period of prescribing drug [29]. In other study, Teich and colleagues reflected that using decision-support system makes five kinds of progress in dose and period of using prescribed drug [미] Evans and colleague introduced advanced decision-support system for prescribing antibiotics in that extent of parameters such as function of patient' kidney, age and sensitivity of cultured organisms were being received and suggestions being presented about drug and its dose and using this system reflected considerable decease in side effects of drug, cost and duration of treatment [31]. Results of Nazzaro and Beary' study reflected that making pharmacy equipped with computer system could increase pharmacy' efficiency by calculating dose of consumed drug for outpatients and decrease time of preparing prescription up to $20 \%$ within two years [32]. Wager considered controlling dose of prescribed drug in proportion to age, weight, and other effective factors on patients as capability of a pharmacy's information system [33]. Asadi and colleagues' study reflected that preparing of medicinal histories of patient and calculating drug dose were being conducted in $46.1 \%$ and $30.7 \%$ of pharmacy's information system of hospitals affiliated to Tehran Shahid Beheshti University of Medical Science, respectively [16]. Making mistake in drug dose is among the preventable prevalent medication errors $[\underline{34}, \underline{35}]$. It is possible to get help from clinical decision support system in pharmacy's information system in order to decrease medical errors and specify patient' secure drug dose. This system can suggest secure drug dose for patients by registering patients' characteristics such as weight, age, height, physiological and psychological parameters, co-morbid disease, consumed drug and patient's reaction to those drugs.

Based on results, the most of experts confirmed capability to register expiration date and way and place of keeping good. Results of functional assessment of hospital information system's soft wares in Iran confirmed that all under-study hospital information system's soft wares do not make it possible to examine the requirement of managing drug inventory [36]. Saghaeiyannejad Isfahani and colleagues' study reflected that soft wares existed in medical centers could not satisfy needed expectations in term of inventory management as one of the input, process and output criteria of pharmacist association [23]. In pharmacy information system, keeping an interior inventory entry of all medicinal products can help to pharmacy's inventory management. When quantity of drug is fewer than usual quantity, pharmacy' information system warns about it and prepares an electronic request that medicinal product would be prepared based on that and in an appropriate quantity from confirmed medicinal producer [17]. 
Table 2: Functional requirements of pharmacy' information system

\begin{tabular}{|c|c|c|c|c|c|c|c|}
\hline Functional Requirement & $\begin{array}{l}0 \\
0 \\
0 \\
0 \\
0 \\
0 \\
0 \\
\\
0 \\
0 \\
0 \\
0 \\
0 \\
0\end{array}$ & 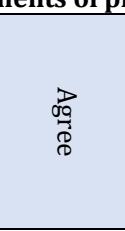 & $\begin{array}{l}z \\
\vdots \\
0 \\
0 \\
3 \\
3 \\
0 \\
0 \\
\stackrel{0}{4}\end{array}$ & 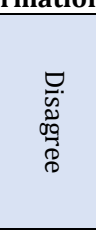 & 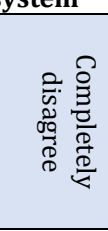 & Total & $\begin{array}{l}\text { Mean of } \\
\text { score out of } 4\end{array}$ \\
\hline $\begin{array}{l}\text { 1.capabiliy to define kind of pharmacy in term } \\
\text { of referring( outpatient, hospitalization, } \\
\text { outpatient and hospitalization) }\end{array}$ & $13(34.2)$ & $22(57.9)$ & $2(5.3)$ & - & $1(2.6)$ & $38(100)$ & 3.21 \\
\hline $\begin{array}{l}\text { 2. capability to define pharmacy, storage and } \\
\text { stoke in unlimited number }\end{array}$ & $13(34.2)$ & $18(47.4)$ & $4(10.5)$ & $3(7.9)$ & - & $38(100)$ & 3.07 \\
\hline $\begin{array}{l}\text { 3. capability to specify kind of pharmacy in } \\
\text { term of referring, special location, surgery } \\
\text { room with possibility of setting calculation of } \\
\text { all items in insurance at time of registering } \\
\text { prescription }\end{array}$ & $15(39.5)$ & $21(55.3)$ & $2(5.3)$ & - & - & $38(100)$ & 3.34 \\
\hline $\begin{array}{l}\text { 4. capability to define different storage ( such } \\
\text { as medicinal storage, consumed goods }\end{array}$ & $15(39.5)$ & $22(57.9)$ & $1(2.6)$ & - & - & $38(100)$ & 3.36 \\
\hline $\begin{array}{l}\text { 5. capability to register expiration date, way } \\
\text { of keeping good and place of keeping good }\end{array}$ & $25(65.8)$ & $12(31.6)$ & $1(2.6)$ & - & - & 38 (100) & 3.63 \\
\hline $\begin{array}{l}\text { 6. capability to warn at time of ending good' } \\
\text { expiration date }\end{array}$ & $25(65.8)$ & $12(31.6)$ & $1(2.6)$ & - & - & $38(100)$ & 3.63 \\
\hline $\begin{array}{l}\text { 7. capability to set medicinal stoke of ward } \\
\text { regarding expiration date and number of drug }\end{array}$ & $16(42.1)$ & $19(50)$ & $3(7.9)$ & - & - & $38(100)$ & 3.34 \\
\hline $\begin{array}{l}\text { 8. capability to enter and calculate drug and } \\
\text { facilities consumed by patients in every shifts } \\
\text { and specify stoke status of drug and facilities } \\
\text { of each wards }\end{array}$ & $19(50)$ & $15(39.5)$ & $4(10.5)$ & - & & $38(100)$ & 3.39 \\
\hline $\begin{array}{l}\text { 9. capability to set maximum inventory, order } \\
\text { and sale threshold for all pharmacies and } \\
\text { stores in exchange for each good }\end{array}$ & $16(42.1)$ & $17(44.7)$ & $4(10.5)$ & $1(2.6)$ & - & $38(100)$ & 3.26 \\
\hline $\begin{array}{l}\text { 10.capability to momently display inventory } \\
\text { of each good in all pharmacies and stores of } \\
\text { hospitals including selling and buying price, } \\
\text { expiration date and existence or non- } \\
\text { existence in shelf }\end{array}$ & $18(48.4)$ & $15(39.5)$ & $3(7.9)$ & - & $2(5.3)$ & $38(100)$ & 3.28 \\
\hline $\begin{array}{l}\text { 11.capability to display consumed inventory } \\
\text { of each good in all pharmacies and stores of } \\
\text { hospitals( zero point) }\end{array}$ & $17(44.7)$ & $17(44.7)$ & $2(5.3)$ & $3(5.3)$ & - & $38(100)$ & 3.28 \\
\hline $\begin{array}{l}\text { 12.capability to warn about minimum } \\
\text { inventory, order and sale threshold for all } \\
\text { pharmacies and stores at time of registering } \\
\text { documents and prescriptions }\end{array}$ & $14(36.88)$ & $19(50)$ & $4(10.5)$ & $1(2.6)$ & - & $38(100)$ & 3.21 \\
\hline $\begin{array}{l}\text { 13.capability to request for transmission } \\
\text { among stores }\end{array}$ & $17(44.7)$ & $14(36.8)$ & $5(13.2)$ & $2(5.3)$ & - & $38(100)$ & 3.21 \\
\hline $\begin{array}{l}\text { 14.capability to electrically refer request of } \\
\text { pharmacy to medicinal storage after } \\
\text { confirming by technical manager of pharmacy }\end{array}$ & $19(50)$ & $14(36.8)$ & $4(10.5)$ & $1(2.6)$ & - & $38(100)$ & 3.34 \\
\hline $\begin{array}{l}\text { 15.capability to compare storage and } \\
\text { pharmacy's inventory with minimum stoke } \\
\text { for each drug and warn in cases that } \\
\text { inventory is of minimum stoke }\end{array}$ & $4(10.5)$ & $4(10.5)$ & $6(15.8)$ & - & - & $38(100)$ & 3.26 \\
\hline $\begin{array}{l}\text { 16.capability to state lack of drug inventory in } \\
\text { pharmacy and medicinal storage at time of } \\
\text { stating request of ward for drug }\end{array}$ & $23(60.5)$ & $11(28.5)$ & $4(10.5)$ & - & - & $38(100)$ & 3.5 \\
\hline 17.capability to register returned drug & $18(47.4)$ & $18(47.4)$ & $1(2.6)$ & $1(2.6)$ & - & $38(100)$ & 3.39 \\
\hline 18.capability to code drug(e.g. NDC) & $13(34.2)$ & $20(52.6)$ & $5(13.2)$ & - & - & $38(100)$ & 3.21 \\
\hline $\begin{array}{l}\text { 19.capability to define different variety of } \\
\text { drug }\end{array}$ & $17(44.7)$ & $17(44.7)$ & $4(1.5)$ & - & - & $38(100)$ & 3.34 \\
\hline $\begin{array}{l}\text { 20. Capability to define variety of default texts } \\
\text { in order to register way of drug consumption } \\
\text { (such as oral, injection, inhaler) }\end{array}$ & $15(39.5)$ & $19(50)$ & $3(7.9)$ & $1(2.6)$ & - & $38(100)$ & 3.26 \\
\hline $\begin{array}{l}\text { 21.capability to define heads of consuming } \\
\text { drug in pregnancy period }(A, B, C, D, X)\end{array}$ & $16(42.1)$ & $13(34.2)$ & $17(18.4)$ & $2(5.3)$ & - & $38(100)$ & 3.13 \\
\hline $\begin{array}{l}\text { 22.capability to define possible status of } \\
\text { requesting drug' importance( little, stat or } \\
\text { maintenance) }\end{array}$ & $14(36.8)$ & $16(42.1)$ & $16(15.8)$ & $2(5.3)$ & - & $38(100)$ & 3.1 \\
\hline
\end{tabular}




\begin{tabular}{|c|c|c|c|c|c|c|c|}
\hline Functional Requirement & 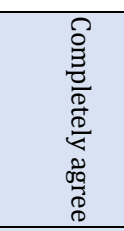 & $\underset{d}{\vec{d}}$ & 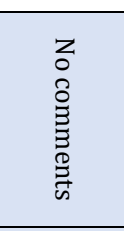 & 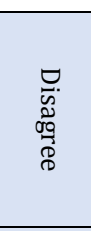 & 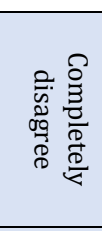 & Total & $\begin{array}{l}\text { Mean of } \\
\text { score out of } 4\end{array}$ \\
\hline $\begin{array}{ll}\text { 23.capability to define patient' gender } & \text { in } \\
\text { order to register information } & \text { of } \\
\text { prescription(female, male) } & \\
\end{array}$ & 11(28.9) & $17(44.7)$ & $9(23.7)$ & $1(2.6)$ & - & $38(100)$ & 3 \\
\hline $\begin{array}{l}\text { 24.capability to define varieties of medicinal } \\
\text { categorization( such as antibiotics, narcotics) }\end{array}$ & $18(47.4)$ & $18(47.4)$ & $1(2.6)$ & $1(2.6)$ & - & $38(100)$ & 3.39 \\
\hline $\begin{array}{l}\text { 25.capability to define varieties of } \\
\text { categorization for items ( such as drug, } \\
\text { consumed facilities, cosmetics) }\end{array}$ & $15(39.5)$ & $18(47.4)$ & $3(7.9)$ & - & $2(5.3)$ & $38(100)$ & 3.15 \\
\hline $\begin{array}{l}\text { 26.capability define varieties of packaging } \\
\text { with its coefficient in order to register number } \\
\text { of good }\end{array}$ & $16(42.1)$ & $16(42.1)$ & $3(7.9)$ & $3(7.9)$ & - & $38(100)$ & 3.18 \\
\hline $\begin{array}{l}\text { 27.capability to register and edit all needed } \\
\text { medicinal and non-medicinal items of hospital }\end{array}$ & $20(52.6)$ & $13(34.2)$ & $4(10.5)$ & $1(2.6)$ & - & $38(100)$ & 3.36 \\
\hline $\begin{array}{l}\text { 28.capability to have medicinal and facilities } \\
\text { entry alphabetically }\end{array}$ & $19(50)$ & $18(47.4)$ & $1(2.6)$ & - & - & $38(100)$ & 3.47 \\
\hline $\begin{array}{l}\text { 29.capability to filter entry of medicinal items } \\
\text { based on search parameters }\end{array}$ & $14(36.8)$ & $20(52.6)$ & $3(7.9)$ & $1(2.6)$ & - & $38(100)$ & 3.23 \\
\hline $\begin{array}{l}\text { 30.capability to print entry of medicinal and } \\
\text { non-medicinal items }\end{array}$ & $18(47.4)$ & $18(47.4)$ & $1(2.6)$ & $1(2.6)$ & - & $38(100)$ & 3.39 \\
\hline $\begin{array}{l}\text { 31.capability to register other additional } \\
\text { information of each drug categorically in } \\
\text { order to needed usage }\end{array}$ & $18(44.7)$ & $15(39.5)$ & $15(13.2)$ & $1(2.6)$ & - & $38(100)$ & 3.26 \\
\hline $\begin{array}{l}\text { 32.capability to register medicinal side effects } \\
\text { of drug }\end{array}$ & $13(34.2)$ & $21(55.3)$ & $4(10.5)$ & - & - & $38(100)$ & 3.23 \\
\hline $\begin{array}{l}\text { 33. management of drug and facilities' entry } \\
\text { through barcode }\end{array}$ & $27(71.7)$ & $30(26.3)$ & $1(2.6)$ & - & - & $38(100)$ & 3.68 \\
\hline $\begin{array}{l}\text { 34. managing filling prescription through } \\
\text { barcode }\end{array}$ & $28(37.7)$ & $(23.7) 9$ & $1(2.6)$ & - & - & $38(100)$ & 3.71 \\
\hline $\begin{array}{l}\text { 35.capability to calculate drug dose based on } \\
\text { medicinal history and physiological } \\
\text { parameter of patient and ability to change } \\
\text { units for consumption }\end{array}$ & $29(76.3)$ & $7(18.4)$ & $2(5.3)$ & - & - & $38(100)$ & 3.71 \\
\hline $\begin{array}{l}\text { 36.capability to recognize and warn about } \\
\text { non-conformity of prescribed drug with } \\
\text { diagnosing the disease and physiology of } \\
\text { patient }\end{array}$ & $25(65.8)$ & $8(2101)$ & $4(10.5)$ & $1(2.6)$ & - & $38(100)$ & 3.5 \\
\hline $\begin{array}{l}\text { 37.capability to make direct connection with } \\
\text { computerized provider order entry }\end{array}$ & 28(73.7) & 11(28.9) & - & - & - & $38(100)$ & 3.73 \\
\hline $\begin{array}{l}\text { 38. Capability to diagnose and warn about } \\
\text { interaction of drug-drug, drug-food, drug- } \\
\text { allergy, drug-results of test and... }\end{array}$ & $27(71.1)$ & $11(28.9)$ & - & - & - & $38(100)$ & 3.71 \\
\hline $\begin{array}{l}\text { 39.capability to warn about riskiness of } \\
\text { prescribed drug for patient }\end{array}$ & $25(65.8)$ & $12(31.6)$ & $1(2.6)$ & - & - & $38(100)$ & 3.63 \\
\hline $\begin{array}{l}\text { 40.access to scientific sources such as review } \\
\text { database and medical studies }\end{array}$ & $21(55.3)$ & $16(42.1)$ & $1(2.6)$ & - & - & $38(100)$ & 3.52 \\
\hline $\begin{array}{l}\text { 41.capability to electronically receive request } \\
\text { and send answers of medicinal counseling of } \\
\text { clinical wards }\end{array}$ & $23(60.5)$ & $12(31.6)$ & $3(7.9)$ & - & - & $38(100)$ & 3.55 \\
\hline $\begin{array}{l}\text { 42.capability to support system of managing } \\
\text { confidential and anonymous danger (such as } \\
\text { giving report of error) }\end{array}$ & $23(60.5)$ & $12(31.6)$ & $2(5.3)$ & - & - & $38(100)$ & 3.52 \\
\hline $\begin{array}{l}\text { 43.capability to electronically receive and } \\
\text { send list of requested drug by clinical wards }\end{array}$ & $23(60.5)$ & 11(28.9) & $4(10.5)$ & - & - & $38(100)$ & 3.5 \\
\hline $\begin{array}{l}\text { 44. capability to determine whether a drug is } \\
\text { narcotic or not }\end{array}$ & $14(36.8)$ & $18(47.4)$ & $5(13.2)$ & - & $1(2.6)$ & $38(100)$ & 3.15 \\
\hline $\begin{array}{l}\text { 45.capability to define varieties of physician' } \\
\text { specialty }\end{array}$ & $14(36.8)$ & $13(34.2)$ & $10(26.3)$ & $1(2.6)$ & - & $38(100)$ & 3.05 \\
\hline $\begin{array}{l}\text { 46.capability to define title of person writing } \\
\text { prescription }\end{array}$ & $10(26.3)$ & $21(55.3)$ & $6(15.8)$ & $1(2.6)$ & - & $38(100)$ & 3.05 \\
\hline $\begin{array}{l}\text { 47.capability to define authorized individuals } \\
\text { who can sign for issuing permit of delivering } \\
\text { drug }\end{array}$ & $14(36.8)$ & $21(55.3)$ & $3(7.9)$ & - & - & $38(100)$ & 3.28 \\
\hline
\end{tabular}




\begin{tabular}{|c|c|c|c|c|c|c|c|}
\hline Functional Requirement & 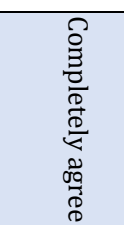 & $\underset{\substack{D \\
\overparen{D}}}{\vec{D}}$ & $\begin{array}{l}z \\
0 \\
0 \\
\vdots \\
3 \\
0 \\
\stackrel{0}{\omega}\end{array}$ & 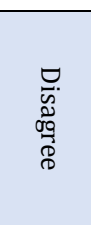 & 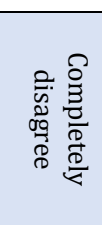 & Total & $\begin{array}{l}\text { Mean of } \\
\text { score out of } 4\end{array}$ \\
\hline $\begin{array}{l}\text { 48.capability to define name of units } \\
\text { authorized to issue permit of delivering drug }\end{array}$ & $15(39.5)$ & $18(47.4)$ & $5(13.2)$ & - & - & $38(100)$ & 3.26 \\
\hline $\begin{array}{l}\text { 49.capability to define verities of permits of } \\
\text { delivering drug }\end{array}$ & $14(36.8)$ & $18(47.4)$ & $6(15.8)$ & - & - & $38(100)$ & 3.21 \\
\hline $\begin{array}{l}\text { 50.capability to define name of companies of } \\
\text { contracting party to register invoice of drug }\end{array}$ & $16(42.1)$ & $19(50)$ & $2(5.3)$ & $1(2.6)$ & - & $38(100)$ & 3.31 \\
\hline $\begin{array}{l}\text { 51.capability to register invoices of buying } \\
\text { and producer and manufacturer companies } \\
\text { and send report to accounting unit }\end{array}$ & $12(31.6)$ & $20(25.6)$ & $6(15.8)$ & - & - & $38(100)$ & 3.15 \\
\hline $\begin{array}{l}\text { 52.capability to define prescription rules for } \\
\text { delivering or not delivering drug including } \\
\text { prescribing by special physician, prescribing } \\
\text { just for special patients, rationing number and } \\
\text { time interval between two prescriptions ( is } \\
\text { important for outpatient patients }\end{array}$ & $15(39.5)$ & $9(50)$ & $3(7.9)$ & $1(2.6)$ & - & $38(100)$ & 3.26 \\
\hline $\begin{array}{l}\text { 53.capability to warn and accurately examine } \\
\text { the prescription rules for delivering or not } \\
\text { delivering drug including prescribing by } \\
\text { special physician, prescribing just for special } \\
\text { patients, rationing number and time interval } \\
\text { between two prescription( is important for } \\
\text { outpatient patients) }\end{array}$ & $14(36.8)$ & $9(50)$ & $5(13.2)$ & - & - & $38(100)$ & 3.23 \\
\hline $\begin{array}{l}\text { 54.capability to register characteristics of } \\
\text { drug producers including characteristics of } \\
\text { company, list of produced drug, dose, shape, } \\
\text { and buying price of drug }\end{array}$ & $13(34.2)$ & $18(47.4)$ & $7(18.4)$ & - & - & $38(100)$ & 3.15 \\
\hline $\begin{array}{l}\text { 55.capability to define drug package to } \\
\text { accelerate selecting number of drug in } \\
\text { document and prescription in unlimited } \\
\text { number with capability to give barcode }\end{array}$ & 11(28.9) & $21(55.3)$ & $4(10.5)$ & $2(5.3)$ & - & $38(100)$ & 3.07 \\
\hline $\begin{array}{l}\text { 56. capability to define verities of working } \\
\text { group in order to separate observing } \\
\text { medicinal items( observing a number of drug } \\
\text { for some users to use in case of having access } \\
\text { permit }\end{array}$ & $12(31.6)$ & $20(52.6)$ & $4(10.5)$ & $1(2.6)$ & $1(2.6)$ & $38(100)$ & 3.07 \\
\hline $\begin{array}{l}\text { 57. Capability to control name and surname of } \\
\text { patient, validity date of health insurance card, } \\
\text { name and surname of physician and medical } \\
\text { counsel number at time of writing } \\
\text { prescription }\end{array}$ & $15(39.5)$ & $18(47.4)$ & $5(13.2)$ & - & - & $38(100)$ & 3.26 \\
\hline $\begin{array}{l}\text { 58.capability to define varieties of titles of } \\
\text { technical right( such as filling prescription on } \\
\text { day and at night) }\end{array}$ & $13(34.2)$ & $20(52.6)$ & $4(10.5)$ & $1(2.6)$ & - & $38(100)$ & 3.18 \\
\hline $\begin{array}{l}\text { 59. capability to set calculating technical right } \\
\text { of outpatients or hospitalization in franchise } \\
\text { percentage of each insurance }\end{array}$ & $14(36.8)$ & $16(42.1)$ & $7(18.4)$ & - & $1(2.6)$ & $38(100)$ & 3.1 \\
\hline $\begin{array}{l}\text { 60.Capability define contracting party with } \\
\text { registering franchise percentage of } \\
\text { Outpatient and hospitalization and } \\
\text { determining insurance ceiling in order to } \\
\text { warn at time of registering patient' } \\
\text { prescription }\end{array}$ & $16(42.1)$ & $20(52.6)$ & $2(6.3)$ & - & $1(2.6)$ & $38(100)$ & 3.36 \\
\hline $\begin{array}{l}\text { 61. capability to determine extent of insurance } \\
\text { ceiling in exchange of each specialty in order } \\
\text { to warn at time of registering patient' } \\
\text { prescription }\end{array}$ & $19(50)$ & $18(47.4)$ & $1(2.6) 1$ & - & - & $38(100)$ & 3.47 \\
\hline $\begin{array}{l}\text { 62. capability to edit information of } \\
\text { insurances of contracting party }\end{array}$ & $14(36.8)$ & $17(44.7)$ & $6(15.8)$ & $1(2.6)$ & - & $38(100)$ & 3.15 \\
\hline $\begin{array}{l}\text { 63. capability to define unit price of accepted } \\
\text { by insurance based on outpatient } \\
\text { prescription, hospitalization prescription and } \\
\text { prescription of special place such as operation } \\
\text { room }\end{array}$ & 15(39.5) & $18(47.4)$ & $5(13.2)$ & - & - & $38(100)$ & 3.26 \\
\hline
\end{tabular}




\begin{tabular}{|c|c|c|c|c|c|c|c|}
\hline Functional Requirement & 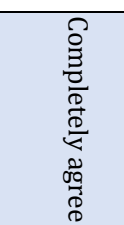 & 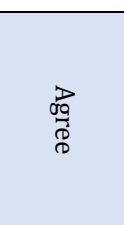 & 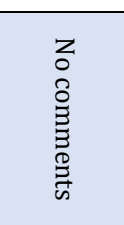 & 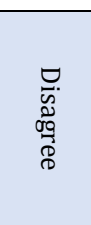 & 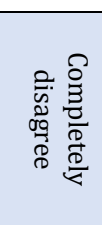 & Total & $\begin{array}{l}\text { Mean of } \\
\text { score out of } 4\end{array}$ \\
\hline $\begin{array}{l}\text { 64. capability to calculate price accepted by } \\
\text { insurance out of selling price of good in } \\
\text { prescription }\end{array}$ & $18(44.7)$ & $18(44.7)$ & $2(5.3)$ & $2(5.3)$ & - & $38(100)$ & 3.28 \\
\hline $\begin{array}{l}\text { 65. capability to print price of patients' } \\
\text { prescription on page of health insurance card } \\
\text { in order to present to insurer organizations }\end{array}$ & $14(36.8)$ & $19(50)$ & $4(10.5)$ & $1(2.6)$ & - & $38(100)$ & 3.21 \\
\hline $\begin{array}{l}\text { 66. Capability to round Cost of patient' portion } \\
\text { in prescription }\end{array}$ & $11(28.9)$ & $20(52.6)$ & $4(10.5)$ & $3(7.9)$ & - & $38(100)$ & 3.02 \\
\hline $\begin{array}{l}\text { 67. capability to set registering OTC } \\
\text { prescription ( registering prescription } \\
\text { without health insurance card) }\end{array}$ & $18(47.4)$ & $11(28.9)$ & $7(18.4)$ & $1(2.6)$ & $1(2.6)$ & $38(100)$ & 3.15 \\
\hline $\begin{array}{l}\text { 68. capability to display messages in case of } \\
\text { not applying insurance because of limitation } \\
\text { of good }\end{array}$ & $14(36.8)$ & $15(39.5)$ & $8(21.1)$ & $1(2.6)$ & - & $38(100)$ & 3.1 \\
\hline $\begin{array}{l}\text { 69. capability to set printing detailed report of } \\
\text { prescription in needed number }\end{array}$ & $14(36.8)$ & $18(47.4)$ & $5(13.2)$ & $1(2.6)$ & - & $38(100)$ & 3.18 \\
\hline $\begin{array}{l}\text { 70. capability to set selecting insurance as } \\
\text { default for registering prescription based on } \\
\text { selecting latest insurer }\end{array}$ & $12(31.6)$ & $18(47.4)$ & $6(15.8)$ & $1(2.6)$ & $1(2.6)$ & $38(100)$ & 3.02 \\
\hline $\begin{array}{l}\text { 71. capability to define accepted number of } \\
\text { drug for insurance for exchange of each } \\
\text { patient' prescription in order to warn at time } \\
\text { of registering prescription }\end{array}$ & $17(44.7)$ & $14(36.8)$ & $7(18.4)$ & - & - & $38(100)$ & 3.26 \\
\hline $\begin{array}{l}\text { 72. capability to register one insurance or } \\
\text { selecting all insurances for covering a good }\end{array}$ & $13(34.2)$ & $18(47.4)$ & $7(18.4)$ & - & - & $38(100)$ & 3.15 \\
\hline $\begin{array}{l}\text { 73. capability to register one insurance or } \\
\text { selecting all insurances for covering all items }\end{array}$ & $14(36.8)$ & $18(44.7)$ & $6(15.8)$ & - & $1(2.6)$ & $38(100)$ & 3.13 \\
\hline $\begin{array}{l}\text { 74. capability to delete one or all insurances } \\
\text { for not covering a good }\end{array}$ & $14(36.8)$ & $17(44.7)$ & $18(21.1)$ & $1(2.6)$ & $1(2.6)$ & $38(100)$ & 3.02 \\
\hline $\begin{array}{l}\text { 75. capability to make similar the tariff of } \\
\text { insurances of contracting party for covering } \\
\text { good }\end{array}$ & $14(36.8)$ & $17(44.7)$ & $6(15.8)$ & $1(2.6)$ & - & $38(100)$ & 3.15 \\
\hline $\begin{array}{l}\text { 76. capability to define specialty limitation for } \\
\text { good in exchange of covered insurances in } \\
\text { order to warn at time of registering patient' } \\
\text { prescription }\end{array}$ & $13(34.2)$ & $19(50)$ & $6(15.8)$ & - & - & $38(100)$ & 3.18 \\
\hline $\begin{array}{l}\text { 77. capability to make similar based on } \\
\text { specialty limitation in exchange of one or few } \\
\text { insurances or insurers }\end{array}$ & $12(31.6)$ & $18(47.4)$ & $7(18.4)$ & - & $1(2.6)$ & $38(100)$ & 3.05 \\
\hline $\begin{array}{l}\text { 78. capability to make similar based on } \\
\text { specialty limitation in exchange of one } \\
\text { insurance of good for other insurances of that } \\
\text { good }\end{array}$ & $12(31.6)$ & $18(47.4)$ & $8(21.1)$ & - & - & $(100) 38$ & 3.1 \\
\hline $\begin{array}{l}\text { 79. capability to have sub-system in order to } \\
\text { introducing herbal and chemical drug of Iran } \\
\text { and world ,including name of drug, names of } \\
\text { other drug, shape and way of effecting, } \\
\text { pharmacokinetic, case of consumption, } \\
\text { consumption prohibition, interference in test } \\
\text { and possible side effects }\end{array}$ & $24(63.2)$ & $8(21.1)$ & $3(7.9)$ & $3(7.9)$ & - & $38(100)$ & 3.39 \\
\hline $\begin{array}{l}\text { 80. capability to define varieties of medicinal } \\
\text { exceptions for hospitalized, outpatients and } \\
\text { lesser than six hours patients }\end{array}$ & $24(63.2)$ & $10(26.3)$ & $4(10.5)$ & - & - & $38(100)$ & 3.52 \\
\hline $\begin{array}{l}\text { 81. capability to dedicate tracking code to } \\
\text { patients' prescription in order to ease nurses } \\
\text { and secretaries' work }\end{array}$ & $23(60.5)$ & $13(34.2)$ & $2(5.3)$ & - & - & $38(100)$ & 3.55 \\
\hline
\end{tabular}

Wager stated that inventory management for keeping correct entry of medicinal store' inventory is among the capability of pharmacy' information system [33]. As a result, it is suggested that these requirements are being considered in designing system by designers in order to manage inventory of pharmacies.

Based on results obtained, the majority of experts had a positive view about existence of requirement of diagnosing and warning about medicinal interference in pharmacy 
information system. Regarding tasks of pharmacy information system, Brown stated that pharmacy information system is responsible for supporting many medical decisions such as controlling amount of drug, controlling interference of drug-drug, drug-food and results of test with drug. This study reflected that 5.6-23\% of side effects are resulted from medicinal interference and pharmacy' information system has capability to control medicinal interference [37]. Results of Alipor and colleagues' study indicated that $73.3 \%$ of physicians confirmed the effect of information systems examining mutual medicinal effect on increasing patient's quality of care [38]. Gharamaleki and colleagues reflected in their study that $95.4 \%$ of clinical specialists had a positive view about implementing electronic design of food-drug interference [39]. Pharmacy information system first was responsible for formation financial management and data management and some main activities of pharmacy information system in that period included preparing pharmacy's invoices, inventory management and preparing reports such as preparing list of delivered drug, preparing medicinal tags and patients histories. Pharmacy information system was being still used for managerial activities and delivering drug and controlling consumption of drug up to middle of 1990. Modern information systems are responsible for supporting many medical decisions such as controlling interference of drugdrug, drug-food and results of test with drug [16]. Considering that importance of medicinal interference is evident, it is suggested that capability to register medicinal interference is paid attention in pharmacy information subsystem by designers of software in order to prevent from medicinal interference and help to make correct decision for prescribing drug and supporting medical activities of pharmacy.

The most of experts had positive view about capability to manage inventory and equipment through barcode and capability to medication through barcode. Poon and colleagues reflected that applying barcode technology in pharmacy before sending drug to the ward of patient care location is followed by $36 \%$ decrease in medication errors and $63 \%$ decrease in side effects of drug [40]. Wager stated that applying medicinal barcode for controlling previous and current drug is among the capability of pharmacy' information system [33]. If all drug in pharmacy have barcode, it is ensured that correct drug with correct dose and formulation would be distributed and errors resulted from drug distribution would be considerably decreased and undoubtedly, applying this technology as effective strategy would be helpful in preventing from medication errors in pharmacy' information system.

Based on findings of present study, the most of experts agreed with possibility of computerized provider order entry and its relation with pharmacy' information system. Results of a study reflected that applying CPOE causes decrease of $55 \%$ in medication errors [34]. Physician may write wrong or imperfect order at time of registering medicinal orders in that dose of drug, method and duration of consumption were omitted. Moreover, additional errors such as illegible medicinal orders or using non-standard expressions in process of prescribing drug are occurred. CPOE is a reasonable way to omit such errors and assures that medicinal orders have been registered completely, legibly and standardly $[\underline{34}, 41]$. Non-existence of relation between CPOE and pharmacy' information system causes doing it twice and re-registering medicinal orders of pharmacy in PIS that this re-registration is followed by errors of duplicating prescription [42]. The advantage of relation of CPOE and PIS is that medicinal orders are being sent to pharmacy faster and errors related to drug with the same name would be decreased [43].

\section{CONCLUSION}

Pharmacy information system has a considerable role in decreasing errors and increasing speed in management of prescription, distribution and medication. Therefore, paying attention to information needs and processes and procedure of users working with this system at time of operating and buying system would be necessary. Results reflected that requirements of system that are in contact with patient security such as using barcode technology, being equipped with decision support system in order to warn about medicinal interference and calculate the correct dose of drug, computerized provider order entry and its relation with pharmacy' information system have been paid more attention by users. Pharmacy information system first was responsible for managerial activities and delivering drug and controlling consumption of drug while it is expected that modern systems are included capabilities in direction of supporting many medical decisions and decreasing medication errors and security of patient; As pharmacy information systems are being continually designed and offered for sale, recognizing requirements of these systems is evident in order to be sure about fulfilling aims and considered advantages. Determined requirements in this study may be useful for designers, companies selling software and managers of medical-health centers specially hospitals and other beneficiaries of hospital information system.

\section{ACKNOWLEDGEMENT}

This work has been supported by the Kashan University of Medical Sciences Research Council [grant number 9056]. We express our sincere and deep gratitude to technical chairmen, interior managers and technician settled in pharmacy of hospitals who supported us in conducting the present research with their insightful opinions and ideas.

\section{REFERENCES}

1. Toruner EK, Uysal G. Causes, reporting, and prevention of medication errors from a pediatric nurse perspective. Aust $\mathbf{J}$ Adv Nurs. 2012; 29(4):28-35.

2. Cina JL, Gandhi TK, Churchill W, Fanikos J, McCrea M, Mitton P, et al. How many hospital pharmacy medication 
dispensing errors go undetected? Jt Comm J Qual Patient Saf. 2006;32(2):73-80. PMID: 16568920 [PubMed]

3. Poon EG, Keohane CA, Yoon CS, Ditmore M, Bane A, Levtzion-Korach O, et al. Effect of bar-code technology on the safety of medication administration. N Engl J Med. 2010;362(18):1698-707. PMID: 20445181. DOI: 0.1056/NEJMsa0907115. [PubMed]

4. Frith KH, Faye Anderson E, Tseng F, Fong EA. Nurse staffing is an important strategy to prevent medication errors in community hospitals. Nurs Econ. 2012; 30(5): 288-94. PMID: 23198612 [PubMed]

5. Handler SM, Nace DA, Studenski SA, Fridsma DB. Medication error reporting in long term care. Am J Geriatr Pharmacother. 2004;2(3):190-6. PMID: 15561651 DOI: 10.1016/j.amjopharm.2004.09.003 [PubMed]

6. Hughes RG, Ortiz E. Medication errors: Why they happen, and how they can be prevented. J Infus Nurs. 2005;105(3):14-24. PMID: 15802994 [PubMed]

7. Leape LL, Bates DW, Cullen DJ, Cooper J, Demonaco HJ, Gallivan T. Systems analysis of adverse drug events. JAMA. 1995;274(1):35-43. PMID: 7791256 [PubMed]

8. Al-Shara M. Factors contributing to medication errors in Jordan: a nursing perspective. Iran J Nurs Midwifery Res. 2011;16(2):158-161. PMID: 22224100 [PubMed]

9. Bates DW. Using information technology to reduce rates of medication errors in hospitals. BMJ. 2000; 320(7237): 78891. PMID: 10720369 [PubMed]

10. Fassett K, Christensen DB. Computer application in pharmacy. European Union: Lea \& Febiger. 1986.

11. CPOE, bedside technology, and patient safety: A roundtable discussion. Am J Health Syst Pharm. 2003; 60(12): 121928. PMID: 12845917 [PubMed]

12. Bates DW, Gawande AA. Improving safety with information technology. N Engl J Med. 2003; 348(25): 2526-34. PMID: 12815139 DOI: 10.1056/NEJMsa020847. [PubMed]

13. Anacleto TA, Perini E, Rosa MB, César CC. Medication errors and drug-dispensing systems in a hospital pharmacy. Clinics. 2005; 60(4): 325-32. PMID: 16138240 DOI: /S1807-59322005000400011. [PubMed]

14. Hebda T, Czar P, Mascara C. Handbook of informatics for nurses and health care professionals. Pearson Prentice Hall; 2005.

15. Abdelhak M, Hanken MA, Grostick S. Health information: Management of a strategic resource. Saunders WB Co; 2000.

16. Asadi F, Moghaddasi H, Hosseini A, Sajjadi S, Maserat E. Pharmacy information systems in Tehran university hospitals and their relationship with pharmaceutical companies. J Paramed Sci. 2011;2(1): 48-55. DOI: 10.22037/jps.v2i1.2149.

17. Biohealthmatics Center. Pharmacy information systems [Internet]. 2009 [2006 Aug 10; cited 2017 Jan 1]. Available from: http://www.biohealthmatics.com/technologies/his /pis.aspx

18. Huffman E. Medical record management. USA: American Medical Record Association (AMRA). 1994.

19. Wolper LF. Health care administration: planning, implementing, and managing organized delivery systems. Jones \& Bartlett Learning; 2004.
20. Hodge MH. Medical information systems: A resource for hospitals. $3^{\text {rd }}$ ED. New York: Aspen System Corporation (ASC); 1997.

21. Collignon U, Oborne CA, Kostrzewski A. Pharmacy services to UK emergency departments: a descriptive study. Pharm world Sci. 2010; 32(1): 90-6. PMID: 19898991 DOI: 10.1007/s11096-009-9347-3 [PubMed]

22. Emami E, Sharifian R, Sotude H, Nourmohammadi A, Asemani Z. Evaluation of hospital information systems of the teaching hospitals affiliated to Shiraz university of medical sciences based on the American College of Physicians criteria. J Health Man \& Info. 2013;1(1):11-4.

23. Saghaeiannejad-Isfahani S, Mirzaeian R, Jannesari $H$, Ehteshami A, Feizi A, Raeisi A. Evaluation of pharmacy information system in teaching, private and social services hospitals in 2011. J Educ Health Promot. 2014; 3(1): 36-41. PMID: 25013832 DOI: 10.4103/2277-9531.131919 [PubMed]

24. Farzandipour M, Sadoughi F, Meidani Z. Hospital information systems user needs analysis: A vendor survey. Journal of Health Informatics in Developing Countries. 2011;5(1): 147-54.

25. Ammenwerth E, Ehlers F, Hirsch B, Gratl G. HIS-Monitor: An approach to assess the quality of information processing in hospitals. Int J Med Inform. 2007; 76(2-3): 216-25. PMID: 16777476 DOI: 10.1016/j.ijmedinf.2006.05.004 [PubMed]

26. McAlearney AS, Hefner JL, Sieck C, Rizer M, Huerta TR. Evidence-based management of ambulatory electronic health record system implementation: An assessment of conceptual support and qualitative evidence. Int J Med Inform. 2014; 83(7): 484-94. PMID: 24862893 DOI: 10.1016/j.ijmedinf.2014.04.002 [PubMed]

27. Romano CA. Development, implementation, and utilization of a computerized information system for nursing. Nurs Adm Q. 1986;10(2):1-9. PMID: 3633437 [PubMed]

28. Bobb A, Gleason K, Husch M, Feinglass J, Yarnold PR, Noskin GA. The epidemiology of prescribing errors: the potential impact of computerized prescriber order entry. Arch Intern Med. 2004;164(7):785-92. PMID: 15078649 DOI: 10.1001/archinte.164.7.785 [PubMed]

29. Chertow GM, Lee J, Kuperman GJ, Burdick E, Horsky J, Seger DL, et al. Guided medication dosing for inpatients with renal insufficiency. JAMA. 2001; 286(22): 2839-44. PMID: 11735759 [PubMed]

30. Teich JM, Merchia PR, Schmiz JL, Kuperman GJ, Spurr $\mathrm{CD}$, Bates DW. Effects of computerized physician order entry on prescribing practices. Arch Intern Med. 2000; 160(18): 2741-7. PMID: 11025783 [PubMed]

31. Evans RS, Pestotnik SL, Classen DC, Clemmer TP, Weaver LK, Orme JF Jr, et al. A computer-assisted management program for antibiotics and other antiinfective agents. $\mathrm{N}$ Engl J Med. 1998; 338(4): 232-8. PMID: 9435330 DOI: 10.1056/NEJM199801223380406 [PubMed]

32. Nazzaro JT, Beary JF. Benefits of a computerized pharmacy. JAMA. 1983; 249(24): 3302-3. PMID: 6854859 [PubMed]

33. Wager KA, Lee FW, Glaser JP. Managing health care information systems: A practical approach for health care executives. John Wiley \& Sons; 2005.

34. Bates DW, Leape LL, Cullen DJ, Laird N, Petersen LA, Teich JM, et al. Effect of computerized physician order 
entry and a team intervention on prevention of serious medication errors. JAMA. 1998; 280(15): 1311-6. PMID: 9794308 [PubMed]

35. Kuperman GJ, Bobb A, Payne TH, Avery AJ, Gandhi TK, Burns G, et al. Medication-related clinical decision support in computerized provider order entry systems: A review. J Am Med Inform Assoc. 2007; 14(1): 29-40. PMID: 17068355 DOI: $10.1197 /$ jamia.M2170 [PubMed]

36. Ministry of Health and Medical Education Statistics and Information Technology Office. The results of performance evaluation hospital information system software. 2010. [In Persian].

37. Brown TR. Handbook of institutional pharmacy practice. ASHP; 2006.

38. Alipour J, Hayavi Haghighi M, Khorami F, Hoseini Teshnizi S, Bonyani L, Karimi F, et al. The impact of medical information systems on health care quality and factors affecting the use of these systems from physician's viewpoints in Hormozgan university of medical sciences. Journal of Health Administration. 2012; 14(46): 47-56.

39. Gharamaleki A, Ahmadi A, Faraji Khiavi F, Arpanahi SH, Jafarian K. Opinions of clinicians towards use of computer applications for detecting drug-food interactions. Payavard Salamat. 2011; 5(1): 58-68.

40. Poon EG, Cina JL, Churchill W, Patel N, Featherstone E, Rothschild JM, et al. Medication dispensing errors and potential adverse drug events before and after implementing bar code technology in the pharmacy. Ann Intern Med. 2006;145(6):426-34. PMID: 16983130 [PubMed]

41. Menachemi N, Brooks RG. Reviewing the benefits and costs of electronic health records and associated patient safety technologies. J Mel Syst. 2006; 30(3): 159-68. PMID: 16848129 [PubMed]

42. Ammenwerth E, Schnell-Inderst P, Machan C, Siebert U. The effect of electronic prescribing on medication errors and adverse drug events: a systematic review. J Am Med Inform Assoc. 2008; 15(5): 585-600. PMID: 18579832 DOI: 10.1197/jamia.M2667 [PubMed]

43. Koppel R, Metlay JP, Cohen A, Abaluck B, Localio AR, Kimmel SE, et al. Role of computerized physician order entry systems in facilitating medication errors. JAMA. 2005; 293(10): 1197-203. PMID: 15755942 DOI: 10.1001/jama.293.10.1197 [ $\underline{\text { PubMed] }}$ 